\title{
Raúl Prebisch
}

\author{
and the development agenda \\ at the dawn of the \\ twenty-first century
}

José Antonio Ocampo*

The hundredth anniversary of the birth of Raúl Prebisch is an invaluable opportunity for us to take another look at the ideas of this great Latin American, one of the thinkers from the developing world who has had the strongest influence in world economic debates. His ideas have been the subject of heavy criticism, but much of this has been based on distorted versions of his thinking or of its practical application, rather than his true intellectual work. Taking his proposals out of their historical context has also been a frequent practice, even by some of his own followers. It should be remembered, in particular, that many of his proposals were made in the light of the collapse of the international trade and financial system in the 1930s, whose reconstruction had barely begun when he published his most influential works (Prebisch, 1949, 1951 and 1952).

This essay tries to show that some of the basic ideas in Prebisch's thinking remain valid, and it reformulates them as a function of ECLAC's most recent proposals and the contributions of other schools of economic thought.

\footnotetext{
* Executive Secretary of ECLAC (jaocampo@eclac.cl). This paper was presented at the seminar on development theory at the dawn of the 21 st century, organized by ECLAC to commemorate the hundredth anniversary of the birth of Raúl Prebisch. The author wishes to express his thanks to Oscar Altimir, María Elisa Bernal, María Angela Parra and Rosemary Thorp for their valuable comments on an earlier version.
}

\section{Three main elements in Prebisch's thinking}

"The spread of technical progress from the countries where it had its source to the rest of the world has been ... relatively slow and irregular" (Prebisch, 1951, p. 3). This assertion, which forms the opening words of what is perhaps his best-known work, has two fundamental methodological implications. The first is the recognition of the key role of technical progress in economic growth and, hence, the importance for the developing countries of the channels through which that progress is transmitted from the "countries of origin": the derived demand for raw materials; technology transfer proper, including technology embodied in production equipment; the transfer to the developing countries of branches of production which are already "mature" in the industrialized countries, and the participation of developing countries in sectors of rapid technological progress. The second is the impossibility of analysing the dynamics of developing countries independently of their position within the world economy. Their development processes are qualitatively different from those of the most advanced nations. This means that there are no uniform "stages of development" and that "late development" -or "peripheral capitalism", to use Prebisch's own term- has a dynamic which is quite different from that of nations which developed earlier and became the "centre" of the world economy. ${ }^{1}$

\footnotetext{
${ }^{1}$ The best analysis of these points of view is undoubtedly that of Furtado (1961).
} 
This is the view which underlies the idea of an inherently hierarchical "centre-periphery" world economic system (or "North-South", if we prefer the terminology which gained currency in the debates of the 1970s). The essence of this view is its emphasis on the basic asymmetries characterizing the world economy, and their persistence over time, in contrast with the perception of the world economy as a place of relations between equals, or a "level playing field", to use a concept which has been in vogue in recent years. In terms of the recent controversies on economic growth, this alternative view of the world economy means that these asymmetries give rise to "divergence" in levels of development, or at the very least represent a serious obstacle to the "convergence" assumed in orthodox economic growth theory. ${ }^{2}$

These asymmetries are reflected primarily in the structure of production. According to a version which is very close to Prebisch's thinking, "unlike the production structure of the periphery, which is specialized and heterogeneous, that of the centres is diversified and homogeneous" (Rodríguez, 2001, p. 105). As technical change originates in the centre countries and they also have higher consumption capacity, at any given moment they tend to have a concentration of the branches of production which are most dynamic at the world level. In Prebisch's view, this gives rise to a tendency towards specialization by the industrialized countries in products of high income elasticity, while the countries on the periphery tend to concentrate on the production of goods of low income elasticity (raw materials and, increasingly, the manufacture of mature goods), which in turn reflects a trend towards divergence of growth rates and /or the rise of balance of payments problems in the latter countries, i.e., an external gap or bottleneck. These problems are particularly severe at times of crisis, reflecting the high cyclical vulnerability of the developing countries to shocks coming from the centre of the world economy.

In Prebisch's view, overcoming the basic asymmetries of the international system requires not only a change in the international economic structure, but also an effort to transform the structures of the

\footnotetext{
${ }^{2}$ In this formulation we are leaving aside the controversy over the terms of trade, which has been given an excessive amount of attention in the analysis of Prebisch's work. We therefore concentrate on the divergence in levels of development or -in terms of the controversy in question- the role played by the deterioration in the factorial terms of trade. See, in this respect, Ocampo (1991).
}

peripheral countries themselves -“development from within", to use Prebisch's original terminology, as recovered by Sunkel (ed., 1991). In terms of the more recent debates, this "development from within" is essential because the accumulation of national human capital and technological capacity ("knowledge capital") and institutional development are essentially endogenous processes. This explains the decisive importance of "programming development", which was a term used in the first stages of ECLAC's work and, in general, designing explicit State strategies to change the internal structures of the country, in order to break down the obstacles to development and make possible new forms of integration into the world economy.

Industrialization was initially seen as the main way of changing the production structure -"spreading technical progress"- and import substitution as its main instrument. This view was in keeping with the characteristics of the period when these ideas were formulated: the absence of a dynamic international market for manufactures; ${ }^{3}$ the "empirical" way in which the import substitution strategy had arisen, as a response to the collapse of the international economy in the 1930s; and the protectionist past which many Latin American countries had shared with the United States and various countries on the European continent, even during the stage of primary-export development. ${ }^{4}$ The possibilities of inefficiency in import substitution, especially in highly fragmented markets, as well as the need to ensure that industrialization was not carried out at the expense of agriculture or export development, were evident to Prebisch even in his earliest publications in ECLAC (Prebisch, 1949, sections I and VI). Therefore, from the late 1950s on, Prebisch and ECLAC began to advocate a "mixed model" which combined import substitution with the promotion of new exports, especially of industrial origin. ${ }^{6}$ Over time, ECLAC's view became increasingly pro-export, although it never

\footnotetext{
3 "No emphasis was placed on exports of manufactures to the centres in this stage, in view of the unfavourable conditions prevailing in those countries and the absence of a suitable industrial infrastructure for this" (Prebisch, 1987, p. 17).

${ }^{4}$ For more details of Latin American protectionism during the export stage, see Cárdenas, Ocampo and Thorp (eds., 2000a, chap. 1). For a comparison of Latin American tariffs with those of a number of Western European countries and the United States, see Maddison (1989, pp. 45-47).

${ }^{5}$ This is the term used in a recent study on economic history (Cárdenas, Ocampo and Thorp, eds., 2000b, chap. 1).

${ }^{6}$ This coincides with what Prebisch called the third stage in his thinking (Prebisch, 1987, pp. 9-21). One of its clearest expressions is to be found in Prebisch, 1963.
} 
favoured the abrupt elimination of protection arrangements. $^{7}$

For Prebisch, the industrialization of the peripheral countries also involved a further problem: modern industry was less able to absorb the surplus labour made available by the rural sector. This fact was further aggravated by technological dependence, which meant that "best practices" corresponded to patterns of labour use dictated by the levels of development of the industrialized countries. One way or another, patterns of development came to be marked by greater "structural heterogeneity" of the productive sectors, to use the term coined later by Pinto (1970): while some workers were absorbed by the high-productivity sectors, a generally much large proportion were relegated to low-productivity sectors. This high level of domestic heterogeneity was one of the basic forces exerting adverse pressures on income distribution, and moreover, in the case of Latin America, this took place in countries which had already inherited a high degree of inequality and marked social segmentation from their previous stages of development.

Under the mixed development strategy, integration processes were seen, from the early 1950s on, as key elements for rationalizing the costs of import substitution: both those associated with the absence of competition and those due to the inefficiency deriving from the sub-optimal scale of the industrial plants. A decade later, when the possibilities of exporting manufactures to the industrialized countries began to be perceived, they were likewise seen as a means of building up export experience, as a prelude to winning other markets. Regional integration -the various subregional processes, LAFTA/LAIA, and the Latin American common market, which was the most ambitious project- thus became a decisive element in the "mixed model" advocated by Prebisch and ECLAC

\footnotetext{
${ }^{7}$ See, in this respect, three recent versions of the history of ECLAC thinking: Bielschowsky (1998), ECLAC (1998) and Rosenthal (2001). The reasons for this view (now mainly of historical interest) were based on three considerations: i) the transmission costs that the elimination of protection arrangements would cause; ii) the idea that the structure of export incentives could be rationalized to offset the costs of protection, and iii) the belief that there was some degree of complementarity between protection and export development; in particular, where economies of scale existed, the local market served as a "base" for winning foreign markets (an argument that Krugman, 1990, chap. 12, subsequently called "import substitution as export promotion"). Prebisch and ECLAC always acknowledged, however, that high levels of protection could give rise to inefficiency and insoluble anti-export biases.
}

from the late 1950s (ECLAC, 1959). Thus, it was seen as a way of expanding the spaces within which "development from within" could take place, in order to make it more efficient.

The asymmetrical features characteristic of the "centre-periphery" system, the need to adopt active "development from within" strategies (including those designed to deal with the special problems caused by "structural heterogeneity") and the critically important role of regional integration are thus three central elements in Prebisch's thinking. In the rest of this paper I shall seek to show their ongoing importance in the development agenda of this dawning twenty-first century.

\section{International asymmetries}

The tendency towards the further expansion of inequalities has been a persistent feature of the world economy for the last two centuries. Empirical studies show that convergence of per capita income levels has been a relatively rare occurrence and has been limited in fact to the most highly industrialized countries in the period after the Second World War and, in particular, during the 1950-1973 "Golden Age". It was not a feature of the industrialized countries before that war (Maddison, 1991), nor has it been a feature of the developing countries since then (Ros, 2000, chap. 1). There have been episodes of rapid growth in the developing world in certain periods, however. In fact, Latin America was the fastest-growing region in the world between the two world wars, and some Asian countries have led the world in growth in some periods after the Second World War: the oil-producing countries of the Middle East, the "Asian Tigers", and China and India in different sub-periods (Maddison, 1995). Except in the case of Japan, however, these processes have not brought about convergence with the patterns of development of the industrialized world, and in most cases they have now been interrupted. It may be added that even within Latin America there is no clear tendency towards convergence: the inequalities which grew up a century or so ago have tended to persist over time (Cárdenas, Ocampo and Thorp, eds., 2000a, chap. 1, and 2000b, chap. 1).

The persistence and even accentuation of these international inequalities has occurred despite the impressive industrialization process registered by the developing countries in the last half-century (and even earlier in Latin America). This process has been reflected in greater diversification of the structure of 
production of the developing world, except in the most backward areas. Serious imbalances have persisted, however, in the structure of production at the world level: there is a high degree of concentration of technical progress in the centre countries, which has determined their sources of competitiveness; they have continued to dominate the world in the production of machinery and equipment, and they also continue to predominate in the make-up of the great transnational corporations.

The most important consequence of the imbalances in the world economy is that the economic opportunities of the developing countries continue to be largely determined by their place within this international hierarchy. There has undoubtedly been some "spread of technical progress" from the centre, through the channels already mentioned. In the words of Prebisch, however, this spread has continued to be "relatively slow and irregular", and its benefits have been distributed unequally among the developing countries, thus maintaining or even accentuating their "structural heterogeneity". Within the context of the "moving target" represented by the world technological frontier (Pérez, 2001), only a few countries -and few sectors and enterprises within them- manage to move faster and thus reduce their technology lag; many others only manage to more or less keep up with the advance of the frontier, and quite a few fall back. ${ }^{8}$

Furthermore, the vulnerability of the developing countries to external shocks continues to be very high and has even tended to worsen with the growing integration of the world economy. The nature of this vulnerability has been changing over the last halfcentury, however. Although the transmission of external shocks through trade -both directly, through lower sales, and indirectly, through the cyclical deterioration in the terms of trade- has continued to be important, financial shocks have now taken on the leading role, repeating patterns which had already been observed in the past in many Latin American countries, especially during the financial boom and bust of the 1920s and 1930s.

This vulnerability is the result of basic imbalances in the financial structures and in macroeconomic dynamics, especially the depth of financial development and the degree of macroeconomic autonomy of the countries (Ocampo, 2001c). There are four basic financial asymmetries: i) the disparity between the size

\footnotetext{
${ }^{8}$ For recent information on this topic, with regard to Latin America, see Katz (2000) and ECLAC (2001a).
}

of the financial markets of the developing countries and the speculative pressures they face ${ }^{9}$ ii) the nature of the currencies in which the external debt is denominated; iii) the structures of maturities provided by the financial markets, and iv) the scope of the secondary markets. These last three characteristics mean that in developing countries, those agents who have access to international markets (the government and large firms) are subject to currency mismatches, while those who do not have such access (small firms) are subject to maturity mismatches, but it is generally impossible to secure a financial structure which simultaneously obviates both these risks. All in all, this means that the financial markets of developing countries are much more "incomplete" than the international markets, so that part of the financial intermediation must necessarily take place through the international market. It also means that international financial integration is integration between unequal partners. ${ }^{10}$

The macroeconomic asymmetries, for their part, are associated with the fact that the international currencies are those of the industrialized countries and with the nature of capital flows: whereas the capital flows among developed countries are of a countercyclical nature (Eatwell and Taylor, 2000), those between developed and developing countries are clearly pro-cyclical. This behaviour is connected with the residual nature of capital flows to developing countries or, to use the terms coined by Palma (2001), the fact that the latter countries are "debtors of last resort".

The overall result of these factors is that whereas the industrialized countries have more leeway for adopting counter-cyclical macroeconomic policies -and this leeway is even greater in the case of the United States than in the other industrialized economies, since the U.S. dollar is the main international currency-, which thus gives rise to a stabilizing response from the financial markets, in contrast the economies of the developing countries largely lack such leeway, since the financial markets tend to accentuate the cycles and the market actors expect the authorities to behave in a pro-cyclical manner. Looking back over the past, this has meant that whereas the industrialized countries were largely able to free themselves from the rules of the gold standard, those rules continue to determine the macroeconomic behaviour of the developing countries and have even become increasingly influential in this

\footnotetext{
${ }^{9}$ See, for example, Council on Foreign Relations, 1999, chap. III. ${ }^{10}$ ECLAC, 2000, chap. 8, and Studart, 1996.
} 
respect. Thus, the macroeconomic imbalances between the centre and the periphery which were characteristic of the gold standard era (Triffin, 1968; Aceña and Reis, eds., 2000) have been further aggravated. Although multilateral arrangements -especially the intervention of the International Monetary Fund-provide short-term relief, they are aimed at ensuring the adoption of austerity measures during crises: a "depression (macro)economics", to use the expression of Krugman (1999). To be more specific, the characteristic feature of the economies of the developing countries is the alternation of boom and depression macroeconomics (ECLAC, 2000, chap. 8, and 2001b).

There is also a further asymmetry in the international economy which is associated with the contrast between the growing mobility of capital and the restrictions on the international mobility of labour, especially less-skilled labour. As Rodrik (1997) has indicated, asymmetries in the international mobility of the different factors of production give rise to pressures in income distribution which favour the most mobile factors and adversely affect the less mobile ones. These imbalances have a "centre-periphery" component in that the developing countries have a relative abundance of the least mobile factors of production: unskilled labour and natural resources. Indeed, the absence of international mobility of labour was seen by Prebisch (1951) as a basic flaw in the international economy which played an essential role in the tendency towards the deterioration of the terms of trade of the developing countries.

Finally, it should be added that the international economy is also marked by basic imperfections which are of a "systemic" rather than a "centre-periphery" nature. The first of these is the contrast between the rapid development of markets and the lag in building global governance, which has led to a sub-optimal supply of "global public goods" (Kaul, Grunberg and Stern, eds., 1999). The second is the enormous difference between the rapid globalization of some markets and the flagrant absence of a true international social agenda or, more precisely, the lack of effective international instruments to ensure the fulfillment of the development goals which are periodically reiterated, most recently in the United Nations Millennium Declaration. The third is the incompleteness of the international agenda, which also has, to some extent, "centre-periphery" dimensions, in view of the absence of issues of great interest to the developing countries, such as international mobility of labour or the more rapid opening-up by the developed countries of markets which are of great interest to the developing nations (Ocampo, 2001a).

The analysis thus indicates that the global agenda should include "systemic" issues, connected with the supply of "global public goods", as well as those connected with the correction of the existing international asymmetries. These "centre-periphery" issues fundamentally involve correction of the asymmetries in the fields of production and technology, the financial and macroeconomic asymmetries which are responsible for the high degree of cyclical vulnerability of the developing countries, and those associated with the different degrees of international mobility of the factors of production.

After the establishment of UNCTAD, under the direct influence of Prebisch, ${ }^{11}$ there was explicit recognition of the need to correct the imbalances which marked, and continue to mark, the international economic system. The pledges with regard to official development assistance and "special and differentiated treatment" for the developing countries in trade were among the partial, albeit relatively frustrating, results of this effort to construct a "new international economic order". In recent decades, however, this approach has been seriously eroded (ECLAC, 2001c, chap. VIII) and has been replaced with an alternative model whereby the basic goal in reordering the international economy should be to ensure a "level playing field" to guarantee the efficient functioning of the free market forces. In this new scheme, the main benefits for the developing countries lie in the eventual dismantling of the industrialized countries" protection of "sensitive" sectors, the guarantees offered for export development by an international trade framework with clear and stable rules, and the design of preventive macroeconomic policies which will serve as automatic protection against international financial volatility. In this approach, the aim of correcting international imbalances is only maintained in terms of the acknowledgement of international responsibility visà-vis the least developed countries, thus repeating at the international level the idea that social policy should be a strategy designed to target State action on the poorest sectors.

Although all these actions are desirable, will they be sufficient in themselves to give rise to greater convergence of development levels? In view of the foregoing considerations, the answer may be no. This

\footnotetext{
${ }^{11}$ See, for example, his first report to UNCTAD (Prebisch, 1964).
} 
agenda does not address the asymmetries which tend to generate divergences in development patterns. Moreover, ensuring a "level playing field" implies imposing restrictions on the developing countries, especially the middle-income ones, which the industrialized countries themselves never faced in earlier periods of their history: standards of intellectual property protection typical of countries that generate technology, and limitations on the adoption of policies designed to promote new sectors of production, whether for the domestic market or for export (Chang, 2001). Finally, the problems generated by a manifestly incomplete set of international financial institutions, together with the policy of less intervention in financial markets in order to avoid "moral hazard" and the measures designed to reduce the risks run by large financial agents (the higher risk weighting proposed in the new Basle Committee bank regulation criteria), may end up by helping to "solve" the problem of capital account volatility in the most undesirable way: by bringing about an excessive rise in the cost of external indebtedness for the developing countries and thus possibly leading to a permanent reduction in capital flows to them.

In these circumstances, the design of a balanced international agenda inevitably calls for the correction of the imperfections in the international economic system through action in three areas: i) the application of mechanisms to speed up the "spread of technical progress" from the centre by different forms of "special and differentiated treatment"; ii) efforts by the international financial institutions to increase the developing countries' leeway for adopting countercyclical macroeconomic policies, to check the concentration of credit by placing resources at the disposal of countries and agents which do not have access to credit on private international markets, and to speed up the financial development of the developing countries, as the only way of offsetting in the long term the imbalances that mark the international financial system, and iii) to ensure that international mobility of labour receives the same attention on the global agenda as the international mobility of capital.

\section{Development from within}

In Prebisch's view, the importance of action to correct the imbalances characterizing the international economic system necessarily involved recognition of the equally important role of the policies adopted by the developing countries themselves to transform their economic and social structures. Correcting those imbalances would help to establish an "enabling environment" for the efforts to generate "development from within".

It is now generally recognized, at the institutional level, that a development strategy must help to generate solid social compacts which will ensure political stability; non-discretional legal systems and forms of behaviour of the agents which will make contracts secure; and an impartial and sufficiently efficient State bureaucracy. Although these institutional frameworks serve as the backdrop for the development process, however, they do not explain the concrete growth impulses that economies receive, nor their exhaustion. ${ }^{12}$ These impulses are related more directly with the matters mentioned in the previous sections: the reduction of macroeconomic and financial vulnerability, the rate of change of the structure of production, and the connections between growth patterns and equity, especially the "structural heterogeneity" of the productive sectors.

\section{a) Reducing macroeconomic and financial vulnerability}

As already noted, the emphasis in the first of these fields has been shifting from trade-related matters, on which Prebisch largely concentrated his attention, to those of financial origin. In this respect, Latin America's experience in recent decades makes it possible to deduce some "stylized facts" which should be borne in mind for designing better macroeconomic policies (ECLAC, 2000 and 2001b; Ffrench-Davis, 1999; Ocampo, 2000):

i) There is no simple definition of macroeconomic stability. The return to fiscal discipline and low rates of inflation has not been reflected in greater stability in real terms, that is to say, in GDP growth and greater employment. Nor has it been reflected in better results in the external accounts, since private deficits have not been kept under control. Consequently, concern for the soundness of the fiscal accounts must be accompanied by measures to prevent the accumulation of unsustainable private deficits.

ii) Real stability is also costly. It gives rise to defensive strategies by firms, which put off their investment

\footnotetext{
${ }^{12}$ In the terminology used by Maddison (1991), they refer to the ultimate causes rather than the immediate causes of economic growth. See also Ocampo (2001b).
} 
decisions, thus causing adverse effects on economic growth. In downward phases of the cycle there are also irreversible losses of both tangible and intangible business assets ("tacit" technological and organizational know-how, trade contacts, reputation of the firm), especially when those phases are accompanied by financial crises. For these reasons, there is an inverse relation between economic growth and real instability. As we shall see below, serious social imbalances are also generated during the cycle.

iii) In financial matters, balance sheets are just as important as flows. Financial crises have been originated not only by unsustainable current account deficits, but also by unsuitable financial structures in the public and especially the private sectors: that is to say, structures which have an excessive proportion of short-term liabilities or are open to risks from higher interest rates or rates of devaluation.

iv) In the absence of a fiscal policy with a medium- or long-term horizon, backed up by suitable institutions (stabilization funds), keeping fiscal deficits low is really a pro-cyclical policy approach. It encourages expansion of spending during boom periods on the basis of transitory public revenue. Subsequently, however, the cuts made due to shortterm falls in revenue aggravate crises and thus lead to further reduction of public sector revenues.

v) In the developing countries, monetary policy autonomy is limited under all exchange-rate regimes. This fact has always been recognized in connection with fixed or semi-fixed exchange-rate systems, but in fact the same thing occurs when interest rates are managed in a pro-cyclical manner in flexible exchange-rate regimes in order to avoid exchange rate fluctuations. In view of the vital role played by the exchange rate in open economies -it is a determinant both of competitiveness and of price levels- some degree of intervention in foreign exchange markets may be necessary, but pro-cyclical management of interest rates is undoubtedly the wrong road to follow. For this reason, in spite of its limitations prudential regulation of capital flows can do a lot to increase the autonomy of monetary policy.

vi) Credibility is not necessarily attained by the use of "automatic pilots". If capital flows are procyclical, explicit renunciation of monetary policy autonomy (as for example by adopting systems based on a currency board or the use of a foreign currency as an anchor) can result in more severe economic cycles. In that case, it is quite possible that the market may not validate the hypothetical increase in "credibility" by reducing the country risk accordingly. Furthermore, the country loses some degree of freedom to cope with external or domestic shocks. In both cases, the private agents may question the sustainability of the rules themselves and the high costs of breaking them. Prudent management of macroeconomic flexibility may therefore be a better way, in the long run, to build up greater policy credibility than the adoption of excessively rigid rules.

These lessons indicate that the concept of macroeconomic stability should be expanded to include not only price stability and the maintenance of low fiscal deficits, but also stability of economic growth rates, employment, the external accounts and the national financial systems, as well as the use of pluriannual horizons in fiscal policy design. They also mean that it must be recognized that the authorities are faced with complex dilemmas in seeking to ensure macroeconomic stability in this broad sense of the term, since there is no simple, straightforward association between its different components.

The most promising approach in order to achieve this result would appear to be to pragmatically combine three sets of policies. The first of these is made up of consistent but flexible macroeconomic policies -fiscal, monetary and exchange-rate-designed to prevent the public and private agents from building up heavy debts, to avoid the generation of imbalances in the most important macroeconomic prices (the exchange rate and interest rates) and in the prices of fixed assets and securities in boom periods, and to facilitate reactivation in the event of crises. The second is a stringent system of prudential regulation and supervision of financial systems, with a clear counter-cyclical orientation, which provides for stricter rules in periods of financial euphoria in order to counteract the increasing risks run by intermediaries at such times. The third element is a "liability policy" designed to ensure that a suitable profile of internal and eternal debt maturities is maintained in the public and private sectors (ECLAC, 2000, chap. 8; Ocampo, 2000).

Prudential regulation of the capital account, applied in periods of euphoria in order to prevent overindebtedness, can play a vital role as a "liability policy", promoting an external finance structure in which longterm liabilities predominate, but also, as already noted, 
as an instrument designed to give monetary policy more leeway to adopt counter-cyclical policies. In the long term, however, the main instrument for breaking the asymmetries typical of the international financial system, which are accompanied by the pro-cyclical macroeconomic performance of the developing countries, is deeper financial development in those countries which will ensure suitable development of the long-term segments of the market and of the corresponding secondary securities markets.

Applying counter-cyclical macroeconomic policies is no easy task, since the international financial markets generate strong incentives to over-spend during periods of financial euphoria and over-adjust during crises. For this reason, counter-cyclical macroeconomic policies of the developing countries must be backed up by suitable international institutions. In particular, international financial institutions must take on the essential function of offsetting the pro-cyclical effect of the financial markets, damping down financial cycles from their source by suitable regulation in the industrialized countries, and must also give the countries more leeway to adopt counter-cyclical policies, both through suitable surveillance and incentives to reduce macroeconomic and financial risks at times of euphoria, and through mechanisms to soften adjustments when there are sudden interruptions in capital flows (Eatwell and Taylor, 2000; Ocampo, 2001c).

\section{b) Dynamic changes in production patterns}

Greater macroeconomic stability, even in the broad sense in which we have defined this term, is a necessary but not of itself sufficient condition for rapid economic growth. This is precisely what the various historical variants of structuralist economic thinking, to which Prebisch belongs, are trying to get across when they emphasize that different economic sectors have very different capacities to "spread technical progress" and, ultimately, boost the economy, generating a strong interaction between structural change, investment and economic growth. In this view, the leading role played by some sectors and companies, which form the "dynamic nucleus" at any given point in time, is the essential element in economic growth.

Many schools of thought have analysed the features of these structural dynamics. Some of them have noted that, because of the complementarity (linkages) between production firms and sectors, the macroeconomic and distributional effects of the growth of a sector can give a strong boost to the growth process or, alternatively, halt it (Rosenstein-Rodan, 1943; Taylor, 1991; Ros, 2000). These sectoral dynamics can give rise to successive phases of imbalance, as noted by Hirschman (1961). Technological dynamics can also give rise to processes of "creative destruction", to use the terminology of Schumpeter (1962, chap. VIII). Since technical knowledge, and indeed knowledge in general, is not transmitted through detailed manuals, the growth path of firms involves an intense adaptation and learning process which is intrinsically linked with the experience acquired in the production process and largely determines the capacity for the accumulation of technical, commercial and organizational know-how (Katz, 1976; Amsden, 2001).

Although other formulations could be used, one which captures the essence of structural dynamics centres on two fundamental concepts: i) innovations and the associated learning processes, and ii) the development of production linkages (ECLAC, 2000, chap. 9; Ocampo, 2001b). In this context, "innovation" must be considered to cover every new way of doing things: not only new technologies, but also the development of new sectors or products, new marketing strategies, and the opening of new markets. In the developing countries, many of these "innovations" are associated with the successful adaptation of technologies and activities developed earlier in the industrialized world, in this case through import substitution and/or export promotion. All innovations, in this broad sense of the term, involve learning and dissemination processes, many of them marked by the generation of dynamic economies of scale. This also applies to technological innovation and the development of new productive sectors, as well as new marketing networks, in which such economies are associated with the reduction of transaction costs over time. The second concept highlights the role of the externalities which the economic agents and sectors generate among themselves (Hirschman, 1961) and which determine the degree of "systemic competitiveness" of the relevant production structures (ECLAC, 1990).

These ideas have been used recently by a number of authors to bring out the need for a production development strategy as a fundamental ingredient of a dynamic developing economy, a long-standing subject in the literature on "late industrialization". In line with an old tradition in industrial policy, Chang (1994) has highlighted the importance of lowering the "coordination costs" associated with the development of new sectors subject to substantial complementarities. 
Rodrik (1999) has pointed out the importance of a "national investment strategy" which would make it possible to give an initial boost to growth, while ECLAC (2000) refers to the need to adopt a structural change strategy. Amsden (2001), for his part, has emphasized the crucial importance of close collaboration between the State and the business sector and the need for "mutual control mechanisms" which establish a link between incentives and results, so that incentives do not simply become a source of "rent-seeking".

This interpretation brings out one of the most important characteristics of successful cases of development in the past: a strong industrialization drive based on firm and close collaboration between the State and the private sector. Can it be that the opening-up of markets will do away with the need for active production development policies?

The results obtained so far in Latin America are not very encouraging in this regard as in the last decade of the twentieth century, the fastest export growth in the economic history of the region was accompanied by only mediocre economic growth. The "destructive" elements deriving from the disintegration of domestic production linkages and national innovation systems have been stronger than the opportunities generated by the expansion of transnational corporations or export development patterns which make highly intensive use of imported inputs or natural resources (ECLAC, 2001a). Figure 1 sums up this situation, showing that the economic growth rate in the 1990s was over two percentage points lower than that of the 1950s to 1970s, but gave rise to a trade deficit similar to that of the 1970s and higher than that of the two earlier decades. Furthermore, as noted in UNCTAD (1999, chap. IV), this adverse shift in the relation between economic growth

FIGURE 1

The trade balance and GDP growth rates

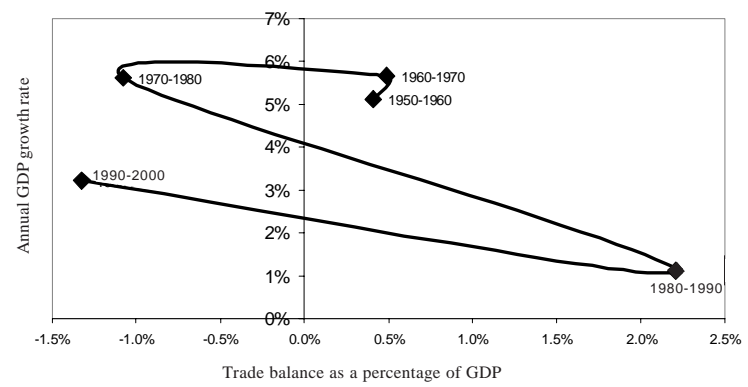

Source: ECLAC. and the trade balance is virtually universal in the developing world.

All this emphasizes the importance of combining macroeconomic stability, in the broad sense, with an active production development strategy. According to the foregoing considerations, the two essential elements of such a strategy are: i) to speed up the rate of innovation, including the transfer of technology, the development of new production sectors and the conquest of new markets, and to support the learning processes involved in all these processes; and ii) to promote the reduction of coordination costs in order to exploit the synergies between enterprises and production sectors which help to generate "systemic competitiveness". This policy requires a considerable institutional and organizational effort in order to develop the right instruments for today's open economies, with a view to playing an active part in international markets. These efforts will have to be all the greater to the extent that the old intervention arrangements have been dismantled or significantly weakened during the liberalization phase of the economies in question.

A policy of this type also requires that the international community should recognize that such strategies are an essential component for dynamic growth of the developing countries. In the light of the problems currently being faced by those countries in seeking to bring about a dynamic change in production patterns, this means that "special and differentiated treatment" must be given in three areas: i) intellectual property protection schemes which help to promote the transfer of technology; ii) temporary promotional arrangements for import substitution industries; and iii) especially in the present conditions, temporary promotional arrangements for new exports ("infant export industries"), through the use of incentives designed to diversify the exportable supply and mechanisms to make it possible to increase the national content of exports (for example, through sectoral agreements backed up by agreements on export performance). All this obviously means seeking the right instruments to ensure that these mechanisms do not give rise to sterile competition among countries to attract industries that are candidates for relocation.

\section{c) The effects of economic changes on equity}

The deep significance of Prebisch's observations on the difficulties that industrialization has faced in the developing countries in general, and in Latin America in particular, in 
absorbing labour is shown in figure 2. Both at the beginning (1950) and the end (1980) of the most rapid industrialization phase, the share of industrial employment in total employment in Latin America was nearly ten percentage points smaller than that which had been displayed by the countries of the Organization for Economic Cooperation and Development (OECD) when (about half a century earlier) they were at the same levels of per capita GDP. Excess labour was absorbed first by the rural sector, but by 1980 the majority of the labour force was employed in urban services. In the light of the form of absorption of excess labour that characterized the mid twentieth century, Prebisch (1951) associated that phenomenon with the deterioration of commodity prices. Three decades later, it had become a source of pressure on urban income distribution in Latin America.

The concept of "structural heterogeneity" developed by Pinto (1970) to take account of this phenomenon is undoubtedly preferable to the traditional concept of "dualism", because the heterogeneity characteristic of developing countries and societies cannot be described simply in terms of the contrast between a "modern sector" and a "traditional sector", since low-productivity sectors are constantly arising and changing, and only a few segments that lag behind can be defined as "traditional". This is what happened in Latin America in the 1990s: the region generated more "world-class" firms (many of them subsidiaries of transnational corporations) capable of successfully integrating into the world economy, but at the same time there was an increase in low-productivity activities, which absorbed seven out of every ten urban workers (ECLAC, 2001a and 2001d).

Structural heterogeneity means that there are no automatic mechanisms which will ensure that rapid technological innovation in dynamic sectors will promote general economic growth. In the absence of suitable internal linkages, or when the "destructive" effects of production restructuring and the defensive microeconomic strategies that accompany them are predominant, structural heterogeneity can even become more pronounced. If this happens, the effects on economic growth will only be weak and there will be still further pressures on employment and equity (see for example Taylor and Vos, 2001).

The linkages between the modernized dynamic sectors and the rest of the economy are therefore important not only for growth but also for equity. Production development strategies can play a fundamental role in promoting such linkages. The evidence also shows that good distribution of assets which gives rise to a universe of solid small enterprises is associated with better income distribution and less concentration of power in general. Policies designed to democratize the access of small urban and rural producers to production assets -capital, technology, training and land- are therefore of the greatest importance, both in terms of growth and of equity.

In addition to these linkages of a structural nature, there are also others associated with macroeconomic volatility: the serious asymmetries in the social effects of business cycles. Thus, in the downward phases of cycles jobs are destroyed and there is an increase in poverty, but when the economy returns to the pre-crisis level of per capita GDP, this does not necessarily mean that there is a return to the previous levels of unemployment or poverty. This is certainly what Latin American history of the last two decades shows: although in the mid-1990s per capita GDP returned to the levels of before the debt crisis, even by the end of

FIGURE 2

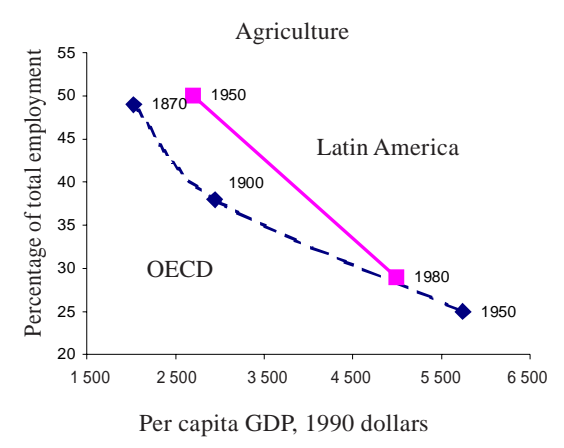

Sectoral structure of employment: Latin America 1950-1980 and OECD 1870-1950
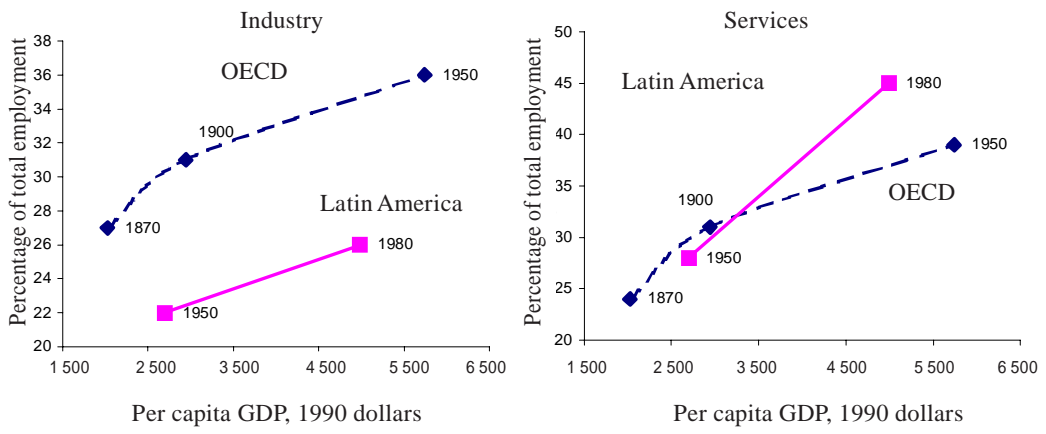

Source: Maddison (1989, 1995).

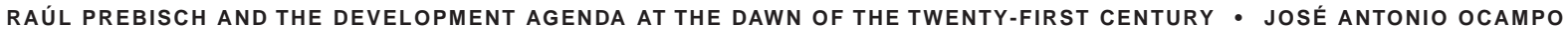


the decade the pre-crisis levels of poverty had still not been restored. It may be added that at the level of the individual, unemployment has a permanent effect on workers' careers: the loss of working experience, reputation and connections means that when workers find employment again they earn significantly lower wages or else are only able to enter the labour market again through self-employment activities (ECLAC, 2001d). The problems are obviously even more serious when the need to contribute to the family's income forces young people to abandon their studies, thus permanently affecting their future careers. Furthermore, when there are no institutions to protect workers against unemployment, unstable demand for labour is in itself costly in social terms.

These interconnections of economic growth patterns with equity highlight a basic fact: equity undoubtedly depends on very active social policy, but it does not depend solely on that. The rate and stability of economic growth are also important, and so too in particular is the way in which patterns of change in the production sector help to reduce or increase "structural heterogeneity". For this reason, even ambitious efforts in the field of education will be futile unless there is dynamic generation of good-quality jobs. When this is absent, the hypothetical connections between human capital accumulation and growth do not materialize, and instead there is still greater "educational devaluation" (occupation of the same jobs by persons of a higher educational level) or emigration of welleducated labour abroad.

The persistent and even increasing levels of urban informal employment and the increase in nonpermanent jobs clearly show the importance of universal, solidary and integral social security policies which include measures to incorporate informal-sector workers and (depending on the degree of development of the countries concerned) to advance towards the provision of unemployment insurance. It is also important to initiate arrangements to promote greater adaptation of the labour force to technological change and to business cycles, so that unemployment will not be the basic means of adjustment: especially arrangements that combine aggressive labour training policies with a "social dialogue" at the national, sectoral or enterprise level in order to restructure production sectors within a framework of stable employment (ECLAC, 2000, chap. 5). Social safety nets and permanent schemes for the timely initiation of emergency employment programmes should be viewed, in this context, as intermediate arrangements that should develop, in the long term, into integral social security systems.

The above-mentioned interconnections also show the importance of designing integrated policy frameworks. One of the weakest points in this respect is the lack of institutions that facilitate this. In the last two decades there has even been a tendency to strengthen the macroeconomic institutions disproportionately, not only over the social institutions but also over those responsible for production development policies. It is therefore necessary to radically reorient the institutional schemes in order to build up systems which make possible coordination between the economic and social authorities, in which social priorities are incorporated as a central part of economic policy design, and which make visible both the immediate and the structural social effects of economic policies.

It should be noted that the foregoing considerations do not of course cover all the positive linkages that can exist between equity and development: apart from the interactions between human capital and good-quality employment and the beneficial effects of better distribution of production assets, there are also favourable economic policy linkages, positive effects on the capital market, and links between social cohesion, investment and productivity. The relations between equity and development were one of the favourite subjects of the development literature of the 1960s, and fortunately they have also come to occupy a leading place in recent economic debate (see for example Ros, 2000, chap. 10). It may be noted, however, that not all connections are positive. Thus, Prebisch's later work (Prebisch, 1976, 1981 and 1987) is full of reflections, based on the Latin American experience of those years, on the way in which pressure on wage levels and public expenditure can generate forms of macroeconomic instability which end up by interrupting economic growth.

\section{Regional integration}

In the classical views of integration associated with Prebisch's thinking, the history of Latin American integration holds a double paradox. On the one hand, the protectionist forces which prevailed in the region in the 1960s and 1970s gave rise to integration processes which fundamentally restricted their scope to noncompetitive sectors. Thus, one of the fundamental virtues of integration, the rationalization of import substitution (ECLAC, 1959), was only achieved to a very

RAÚl PREBISCH AND THE DEVELOPMENT AGENDA AT THE DAWN OF THE TWENTY-FIRST CENTURY • JOSÉ ANTONIO OCAMPO 
limited extent. Moreover, during the debt crisis of the 1980s the regional integration schemes were on the point of collapsing because of the generalized use of protection and competitive devaluation as means of adjusting the economies.

The vigour displayed by the regional integration process from the late 1980 s on was likewise paradoxical, for in the most orthodox views that dominated development concepts at that time integration was seen as a source of distortion of trade flows. The fact that unilateral trade openness coincided with the revitalization of regional integration was therefore a belated concession to the views which had served to justify regional integration in previous periods and, in particular, to the idea that integration was a source of creation rather than diversion of trade and, moreover, a source of trade flows with a greater content of technology than those resulting from unilateral openness.

These virtues have in fact materialized in practice. Thus, the growth of intra-regional trade was extremely vigorous between 1990 and 1997, especially in the two South American integration agreements -MERCOSUR and the Andean Community- where such trade grew by a factor of 5 and 4.2, respectively, during those years. As a result, there was a reversal of the historical situation whereby the intensity of intra-regional trade was greater for the smaller economies. By 1997, the greatest relative intra-regional trade flows were in MERCOSUR. All the regional integration agreements still have a long way to go, however, if the yardstick is the European Union, where intra-regional trade has represented around 60\% of total trade in recent decades. It should also be noted that intra-regional trade suffered a pronounced drop with the Asian crisis. The hardest-hit flows were those among South American countries, but these recovered strongly in the year 2000. This indicates that the elasticity of such trade to economic activity is now very high (ECLAC, 2001c).

Furthermore, the intra-regional trade flows consist to a substantial extent of manufacturing goods, especially those of higher technological content. This pattern is particularly evident if we exclude Mexico, whose sales of manufactures to the United States have grown rapidly since the signing of the North American Free Trade Agreement. In 1999, for example, $81 \%$ of intra-regional exports corresponded to manufactures, compared with $65 \%$ of total external sales (excluding Mexico). The contrast is even greater when only nontraditional products are included. In this case, intraregional trade then absorbed $35 \%$ of exports of manufactures, concentrated in products with the highest content of technology.

The view that there is a relation of complementarity between general trade openness processes and integration was branded by ECLAC (1994) as "open regionalism". This complementarity indicates that, in spite of the advances made in information and communications, external economies and economies of scale (including economies of specialization) and the transaction costs associated with geographical distance continue to be substantial. The latter include not only transport costs, but also those associated with the establishment of trade networks, especially those involving small and medium-sized firms. Regional processes also make it possible to advance further in the harmonization of the rules affecting economic activity and to promote deeper economic relations which also have effects on trade. This is why regional networks create additional trade, over and above that created through unilateral trade openness.

It should be noted, however, that the new regionalism differs from similar efforts made in the past because of the increased number of areas of action involved and the scope of tariff liberalization. Nevertheless, efforts to secure convergence of the existing agreements in order to form areas of larger relative scale and measures to build up customs unions continue to be pending issues, and the existing institutions are still somewhat fragile.

In addition to trade itself, the future of regional integration also clearly depends on the "depth" of the corresponding agreements. In this era of globalization, the space available for regional-level arrangements depends on two different forces. The first of these is the tendency towards the weakening of national autonomy, which means that the efficacy of policies is shifting to the regional or global levels. The second is the relative weight, in these processes, of two factors: i) the regional (rather than the global) scope of the "public goods" that it is sought to promote; if they are not of truly global scope, the principle of subsidiarity would indicate that they should be handled at an intermediate (regional) level; ii) the capacity of the different institutions to generate a sense of "ownership"; from this point of view, the subregional and regional levels are at a marked advantage.

In macroeconomic and financial matters, the loss of autonomy is obviously an ongoing process, so that, as we already noted, there is a need not only for global action, but also for arrangements at the regional level. Possible coordination of macroeconomic policies could 
be a first area for action. Indeed, the demand for action of this type has been heightened by the great vulnerability of intra-regional trade to the recent business cycles. However, the difficulties involved in this process have been brought out clearly in the three decades of experience accumulated by the European countries in this field. In the short term, therefore, the objectives in this respect should be relatively modest.

A measure which is highly complementary to the foregoing would be the establishment of mechanisms to coordinate policies for the prudential regulation and supervision of financial systems. A desirable objective in this field would be the development of mechanisms for the mutual supervision of such policies and, perhaps, the design of minimum standards which are more specific than those of the Basle Rules. The fact that some of the main international banks are operating in a number of countries of the region further emphasizes the importance of coordination in this area, in order to secure more suitable regulation and supervision and to avoid arbitrage by these banks between different regulatory systems.

As emphasized in ECLAC (2001b), similar attention should be given to the development of regional and subregional financial institutions. In this respect, Latin America and the Caribbean already possess important assets in the form of a network of multilateral development banks comprising the Inter-American Development Bank, the Andean Development Corporation, the Central American Bank for Economic Integration, and the Caribbean Development Bank. Furthermore, the experience already built up by the Latin American Reserve Fund (FLAR, formerly the Andean Reserve Fund) opens up the possibility of giving support to countries in crisis with extraordinary resources of regional origin, either through significant expansion of the membership and resources of FLAR, or through mutual support arrangements (through swaps) between Central Banks.

The advance of trade itself also creates a demand for harmonization of the different regulatory schemes. This includes harmonization of technical regulations (including phytosanitary regulations), customs codes, government purchasing standards, and those governing the supply of services. Some progress has already been made in some of these fields in the region. It is also important to make similar progress in other fields, especially as regards rules on competition and the regulation of public utilities. With respect to the firstnamed of these, it may be noted that there are reasons for believing, on the basis of the experience of Europe, that as common markets and an active process of intraregional investment become more firmly established, regional agreements on competition, and the eventual adoption of a common policy on competition, have obvious advantages over rules on unfair competition which apply solely to foreign trade. Among other things, a framework of this type would also make it possible to cope more effectively with possible anti-competitive practices by big transnational corporations.

Furthermore, the considerable proportion of goods with a high technological content in intra-regional trade points to the possibility of joint action to develop the corresponding sectors, but of course without the rigidities of the old (and mostly unsuccessful) sectoral complementation agreements. Such action should rather form part of broader schemes to complement the efforts being made in the field of technological research and development, which should also serve as a means for the transfer of technology to the relatively less developed countries.

In the area of physical infrastructure, in addition to developing harmonized rules on transport, energy and telecommunications it is extremely important to develop infrastructural networks conceived with a view to regional and not solely national integration. The development of infrastructure with this aim in view also highlights the need to visualize spaces as common rather than purely national. An interesting case in this respect was the establishment in 1994 of the Association of Caribbean States, in order to promote greater cooperation in that subregion. Steps have also been taken towards this type of objective in the case of sustainable development, specifically of shared ecosystems (the Amazon and Andean areas, or the Mesoamerican Corridor) or river basins. The establishment of various plans for border area development is another example of the change caused by integration.

Going beyond all this, there are also the immense possibilities opened up by social and political integration. The agreements on cultural matters and education -some of them associated with the first stages of integrationare only the first small step towards an integration agenda centered on social development. The "democratic clauses" of integration agreements and the various forums in which the Heads of State of the region now meet, together with the incipient subregional and Latin American parliaments, are further examples of promising initiatives on the broad agenda of political integration.

These considerations show that regional integration, based on the principles of open regionalism, has a

RAÚl PREBISCH AND THE DEVELOPMENT AGENDA AT THE DAWN OF THE TWENTY-FIRST CENTURY • JOSÉ ANTONIO OCAMPO 
promising future whose actual materialization will depend on the political will of the parties concerned. Indeed, their ability to survive within a hemispheric free trade area or within the process of globalization will depend on their capacity to deepen their achievements by further developing the agenda outlined above.

At all events, Prebisch's categorical admonition continues to be fully valid, not only in relation to trade but also to the international economic (and political) system as a whole: "There is an aspect of fundamental importance to which the governments of the developing countries have not paid sufficient attention. We have not yet managed to break out of the isolation these countries inherited from the old pattern of the international division of labour. Thus, the greater part of world trade has been among the centres themselves. The trade of the developing countries has converged on those centres, overlooking the enormous potential of mutual trade, although it should be recalled that, ever since its earliest days, ECLAC has vigorously advocated such a structural reform of world trade" (Prebisch, 1987, p. 29).

(Original: Spanish)

\section{Bibliography}

Aceña, M. P. and J. Reis (eds.) (2000): Monetary Standards in the Periphery: Paper, Silver and Gold, 1854-1933, New York, St. Martin's Press.

Amsden, A. (2001): The Rise of "The Rest": Challenges to the West from Late Industrializing Countries, New York, Oxford University Press.

Bielschowsky, R. (1998): Cincuenta años de pensamiento de la CEPAL: una reseña, in ECLAC (Economic Commission for Latin America and the Caribbean), Cincuenta años de pensamiento en la CEPAL: textos seleccionados, Mexico City, Fondo de Cultura Económica.

Cárdenas, E., J. A. Ocampo and R. Thorp (eds.) (2000a): The Export Age: The Latin American Economies in the Late Nineteenth and Early Twentieth Centuries. An Economic History of Twentieth Century Latin America, vol. I, New York, St. Martin's Press.

(2000b): Industrialisation and the State in Latin America: The Post War Years. An Economic History of Twentieth Century Latin America, vol. III, New York, St. Martin's Press.

Chang, H. (1994): The Political Economy of Industrial Policy, London, Macmillan.

(2001): Infant industry promotion in historical perspective. A rope to hang oneself or a ladder to climb with?, paper presented at the seminar on development theory at the dawn of the twenty-first century, Santiago, Chile, ECLAC, 2829 August.

Council on Foreign Relations (1999): Safeguarding Prosperity in a Global Financial System: The Future International Financial Architecture, in C. A. Hills, P. G. Peterson (Chairs) and M. Goldstein (Project Director), Task Force Report, Washington, D.C., Institute for International Economics (IIE).

Eatwell, J. and L. Taylor (2000): Global Finance at Risk: The Case for International Regulation, New York, The New Press.

ECLAC (1959): The Latin American Common Market, E/CN.12/531, Mexico City, July.

(1990): Changing Production Patterns with Social Equity, LC/G.1601-P, Santiago, Chile. United Nations publication, Sales No. E.90.II.G.6.

(1994): Open Regionalism in Latin America and the Caribbean. Economic Integration as a Contribution to
Changing Production Patterns with Social Equity, LC/G.1801/ Rev.1-P, Santiago, Chile. United Nations publication, Sales No. E.94.II.G.3.

(1998): Fifty years of the Economic Survey, Economic Survey of Latin America and the Caribbean, 1997-1998, LC/G.2032-P, Santiago, Chile.

(2000): Equity, Development and Citizenship, LC/G.2071(SES.28/3), Santiago, Chile.

(2001a): Una década de luces y sombras. América Latina y el Caribe en los años noventa, Bogotá, Alfaomega.

(2001b): Crecer con estabilidad: el financiamiento del desarrollo en el nuevo contexto internacional, Bogotá, Alfaomega.

(2001c): Latin America and the Caribbean in the World Economy, 1999-2000, LC/G.2085-P, Santiago, Chile.

(2001d): Social Panorama of Latin America, 2000-2001, Santiago, Chile.

Ffrench-Davis, R. (1999): Macroeconomía, comercio y finanzas para reformar las reformas en América Latina, Santiago, Chile, McGraw Hill-Interamericana.

Furtado, C. (1961): Desenvolvimento e subdesenvolvimento, Rio de Janeiro, Editora Fundo de Cultura.

Hirschman, A. O. (1958): The Strategy of Economic Development, New Haven, Yale University.

Katz, J. (1976): Importación de tecnología, aprendizaje e industrialización dependiente, Mexico City, Fondo de Cultura Económica.

(2000): Reformas estructurales, productividad y conducta tecnológica en América Latina, Santiago, Chile, ECLAC/Fondo de Cultura Económica.

Kaul, I., I. Grunberg and M. A. Stern (comps.) (1999): Global Public Goods: International Cooperation in the 21st Century, New York, United Nations Development Programme (UNDP).

Krugman, P. (1990): Rethinking International Trade, Cambridge, Massachusetts, The MIT Press.

(1999): Depression economics returns, Foreign Affairs, New York, Council on Foreign Relations, January-February. Maddison, A. (1989): The World Economy in the 20th Century, Paris, Organization for Economic Cooperation and Development (OECD), Development Centre. 
(1991): Dynamic Forces in Capitalist Development: A LongRun Comparative View, New York, Oxford University Press.

(1995): Monitoring the World Economy 1820-1992, Paris, OECD, Development Centre.

Ocampo, J. A. (1993): Terms of trade and center-periphery relations, in O. Sunkel (ed.), Development from Within. Toward a Neostructuralist Approach for Latin America, Boulder, Colorado, Lynne Rienner Publishers

(2000): Developing Countries' Anti-Cyclical Policies in a Globalized World, "Temas de coyuntura" series, No. 13, Santiago, Chile, ECLAC.

(2001a): The development agenda revisited, CEPAL Review, No. 74, LC/G.2135-P, Santiago, Chile, ECLAC. (2001b): Structural Dynamics and Economic Development, Kurt Martin lecture, The Hague, The Netherlands, Institute of Social Studies, April.

(2001c): International Asymmetries and the Design of the International Financial System, "Temas de coyuntura" series, No. 15, Santiago, Chile, ECLAC.

Palma, G. (2001): Three-and-a-half cycles of 'mania, panic and [asymmetric] crash': East Asia and Latin America compared, in H. Chang, G. Palma and D. H. Whittaker (eds.), Financial Liberalization and the Asian Crisis, New York, Palgrave Publishers.

Pérez, C. (2001): Technological change and opportunities for development as a moving target, CEPAL Review, No. 75, LC/G.2150-P, Santiago, Chile, ECLAC, December.

Pinto, A. (1970): Naturaleza e implicaciones de la 'heterogeneidad estructural' de la América Latina, El trimestre económico, vol. XXXVII(1), No. 145, Mexico City, Fondo de Cultura Económica. Also published in EClaC, Cincuenta años de pensamiento en la CEPAL: textos seleccionados, vol. 1, Mexico City, Fondo de Cultura Económica, 1998.

Prebisch, R. (1949): Introduction: The economic development of Latin America and its principal problems, Economic Survey of Latin America 1948, Santiago, Chile, ECLAC. Also published in ECLAC, Cincuenta años de pensamiento en la CEPAL: textos seleccionados, vol. 1, Mexico City, Fondo de Cultura Económica, 1998.

(1951a): Growth, disequilibrium and disparities: Interpretation of the process of economic development, Economic Survey of Latin America 1949, E/CN.12/164/Rev.1, Santiago, Chile, ECLAC. Also published as: "Interpretación del proceso de desarrollo latinoamericano en 1949", in ECLAC, XXV años de la CEPAL, Santiago, Chile, 1973.

(1951b): Theoretical and Practical Problems of Economic Growth, Mexico City, ECLAC, 18 May. Also published in CEPAL, XXV años de la CEPAL, Santiago, Chile, 1973.

(1963): Hacia una dinámica del desarrollo latinoamericano, Mexico City, Fondo de Cultura Económica.
(1964): Nueva política comercial para el desarrollo, Mexico City, Fondo de Cultura Económica.

(1976): A critique of peripheral capitalism, CEPAL Review, No. 1, E.76.II.G.2, Santiago, Chile, ECLAC, first semester.

(1981): Capitalismo periférico. Crisis y transformación, Mexico City, Fondo de Cultura Económica.

(1987): Cinco etapas de mi pensamiento sobre el desarrollo, in ECLAC, Raúl Prebisch: un aporte al estudio de su pensamiento, LC/G.1461, Santiago, Chile.

Rodríguez, O. (2001): Fundamentos del estructuralismo latinoamericano, Comercio exterior, vol. 51, No. 2, Mexico City, Banco Nacional de Comercio Exterior (BANCOMEXT).

Rodrik, D. (1997): Has Globalization Gone Too Far?, Washington, D.C., Institute for International Economics (IIE).

(1999): The New Global Economy and Developing Countries: Making Openness Work, Policy essay No. 24, Washington, D.C., Overseas Development Council.

Ros, J. (2000): Development Theory and The Economics of Growth, Ann Arbor, Michigan, The University of Michigan Press, September.

Rosenthal, G. (2001): The contribution of the Economic Commission for Latin America and the Caribbean to the United Nations' intellectual legacy, in United Nations, United Nations Intellectual History Project. Views from the Regional Commissions: ECLAC, vol. XII, New York.

Rosenstein-Rodan, P.N. (1943): Problems of industrialization of Eastern and South-Eastern Europe, The Economic Journal, vol. 53, London, Macmillan and Co., Ltd., June-September.

Schumpeter, J. (1962): Capitalism, Socialism and Democracy, New York, Harper Torchbooks.

Studart, R. (1996): The efficiency of the financial system, liberalization and economic development, Journal of PostKeynesian Economics, vol. 18, No. 2, Arkmon, New York, M. E. Sharpe, Inc.

Sunkel, O. (ed.) (1993): Development from Within. Toward a Neostructuralist Approach for Latin America, Boulder, Colorado, Lynne Rienner Publishers.

Taylor, L. (1991): Income Distribution, Inflation and Growth, Cambridge, Massachusetts, The MIT Press.

Taylor, L. and R. Vos (2001): Liberalización de la balanza de pagos en América Latina. Efectos sobre el crecimiento, la distribución y la pobreza, in E. Ganuza, R. Paes de Barros, L. Taylor and R. Vos (eds.), Liberalización, desigualdad y pobreza: América Latina y el Caribe en los 90, Buenos Aires, University of Buenos Aires/UnDP/ECLAC.

Triffin, R. (1968): Our International Monetary System: Yesterday, Today, and Tomorrow, New York, Random House.

UNCTAD (United Nations Conference on Trade and Development) (1999): Trade and Development Report, 1999, Geneva. 